\title{
Pengajaran Bahasa Arab (Studi Minat Belajar Dan Kemampuan Berbicara Siswa)
}

\author{
Fitriatus Sholihah \\ Institut Agama Islam Negeri Metro, Indonesia \\ fitriatussholihah11@gmail.com \\ Akla \\ Institut Agama Islam Negeri Metro, Indonesia \\ akla@metrouniv.ac.id \\ Walfajri \\ Institut Agama Islam Negeri Metro, Indonesia \\ walfajri@metrouniv.ac.id
}

\begin{abstract}
This study aimed to analyze the level of learning interest and Arabic speaking ability of students in Islamic Junior High School. This research method was quantitative with a survey approach. The study was conducted at Islamic Junior High School 2 central Lampung. Samples of this study were 52 students of grade VIII. The data collection method used a questionnaire and test. The questionnaire method was aimed to students to get data on the level of students' interest in learning Arabic and the test method was used to get data on the level of students' Arabic speaking ability. The data analysis technique was descriptive quantitative. The results showed that the level of student interest in learning Arabic was low and the level of ability to speak Arabic was less. Low of interest and speaking ability due to the students' learning environment that was not conducive. The learning environment did not support in increasing speaking ability. The lack of support from the environment would cause a sense of disinterest of students in the Arabic learning process. So that the goal of increasing interest in learning and speaking ability would not be achieved.
\end{abstract}

Keywords: Arabic teaching, learning interest, speaking ability. 


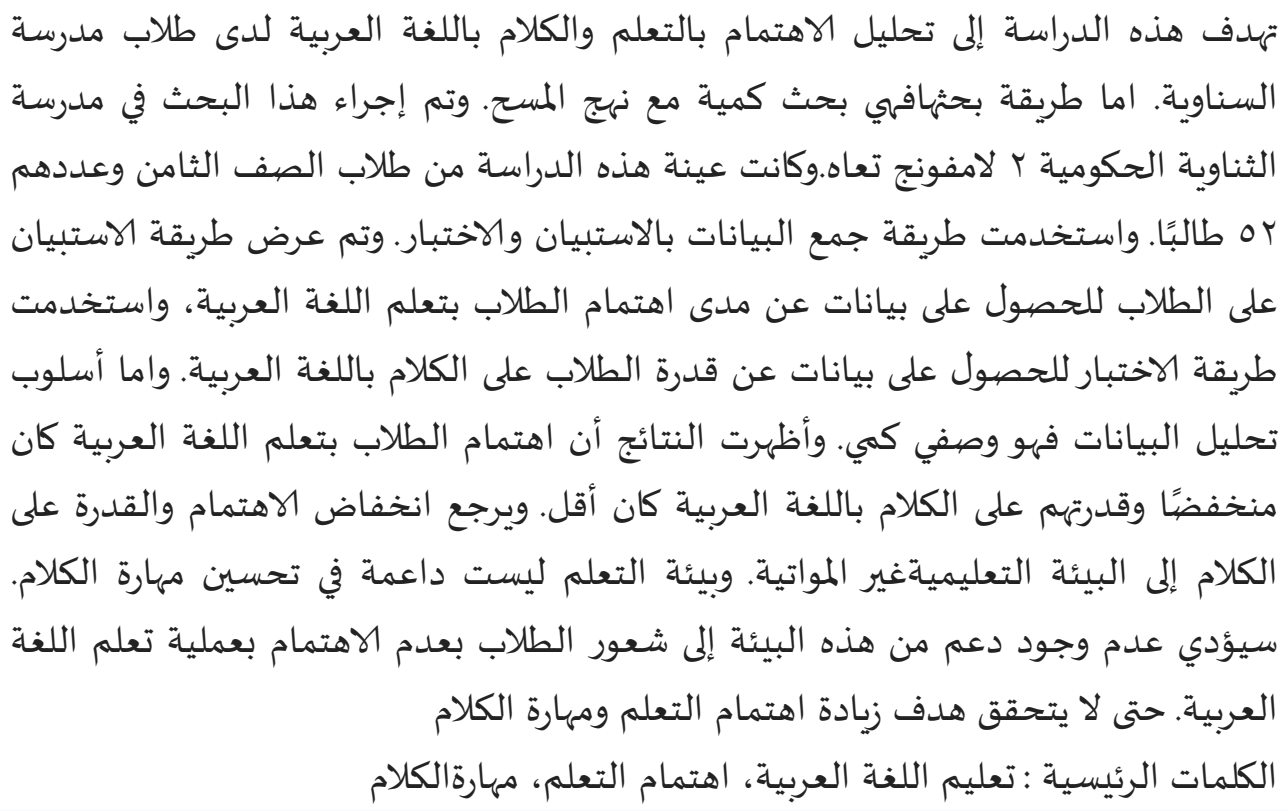

Studi ini bertujuan menganalisis tingkat minat belajar dan tingkat kemampuan berbicara bahasa Arab siswa Madrasah Tsanawiyah. Metode penelitian ini adalah kuantitatif dengan pendekatan survey. Penelitian dilakukan di Madrasah Tsanawiyah Negeri 2 Lampung Tengah. Sampel dari penelitian ini adalah siswa kelas VIII berjumlah 52 siswa. Metode pengumpulan data menggunakan angket dan test. Metode angket ditunjukkan kepada siswa untuk mendapatkan data tingkat minat belajar bahasa Arab siswa dan metode test digunakan untuk mendapatkan data tingkat kemampuan berbicara bahasa Arab siswa. Adapun teknik analisis data yaitu kuantitatif deskriptif. Hasil penelitian menunjukkan bahwa tingkat minat belajar bahasa Arab siswa rendah dan tingkat kemampuan berbicara bahasa Arab kurang. Rendahnya tingkat minat dan kemampuan berbicara disebabkan oleh lingkungan belajar siswa yang tidak kondusif. Lingkungan belajar tidak mendukung dalam meningkatkan kemampuan berbicara. Tidak adanya dukungan dari lingkungan tersebut akan menimbulkan rasa tidak tertarik dalam diri siswa pada proses belajar bahasa Arab. Sehingga tujuan peningkatan minat belajar dan kemampuan berbicara tidak akan tercapai.

Kata kunci: Pengajaran bahasa Arab, minat belajar, kemampuan berbicara

\section{Pendahuluan}

Pengajaran bahasa Arab pada siswa Madrasah Tsanawiyah menghadapi berbagai tantangan dan kesulitan yang mengakibatkantujuan pembelajaran tidak tercapai sesuai yang diinginkan terutama pada aspekkemampuan berbicara. Diantara beberapa kesulitan yang dialami siswadalam penguasaan kemampuan berbicaradisebabkan oleh rendahnya minat belajardan fasilitas yang tidak mendukung yang menjadikan pembelajaran menjadi tidak menarik dan terkesan monoton. Hasil penelitian dari Qomariah dan R Sudiarditha 
menunjukkan bahwa $12,6 \%$ hasil belajar seorang siswa akan dipengaruhi minat belajar siswa. Hasil belajar yang dimiliki siswa ini dipengaruhi oleh tingginya minat belajar(Qomariah \& R Sudiarditha, 2017). Pada penelitianMainizar menunjukkan bahwa minat berkomunikasi siswa yang merupakan kesenangan siswa dalam melakukan percakapan dan bertukar pikiran pada lawan bicara sebesar 78,80\%. Hal ini disebabkan tingginya minat siswa untuk bisa menguasai bahasa Arab untuk berkomunikasi dengan teman-temannya di kelas ketika proses belajar bahasa Arab berlangsung. Apabila seorang siswa memiliki minat berkomunikasi bahasa Arab yang tinggi, maka seorang siswa akan aktif di kelas dengan bertanya ketika kesulitan dan masih ada yang belum difahami kepada guru dan tidak akan takut salah untuk mencoba berkomunikasi menggunakan bahasa Arab(Mainizar, 2011).

Beberapa kesulitan yang dialami siswa Madrasah Tsanawiyah pada pembelajaran bahasa Arab yang dipicu dari dua macam kesulitan yaitupertama bersumber pada kesulitan minat belajar siswa yang rendah dikarenakan tidak ada ketertarikan siswa mengikuti belajar bahasa Arab, kedua kesulitan kemampuan berbicara yang tidak berorientasi pada pelibatan siswa dalam belajar bahasa Arab. Sejauh ini penelitian bahasa Arab di Madrasah Tsanawiyah cendrung menganalisa dua isu utama.Pertama penelitian yang menganalisa tentang minat belajar yang mempengaruhi kemampuan berbicara bahasa Arab siswa(Nurhasanah \& Sobandi, 2016; Ricardo \& Meilani, 2017; Tambunan, 2016).Kedua kemampuan berbicara yang bisa dikuasai siswa dengan baik sesuai dengan tujuan pengajaran bahasa Arab (Hernawati, 2007; Setyonegoro, 2013; Tarigan, 2015).

Penelitian ini melengkapi penelitian yang sudah ada dan cenderung mengabaikan peningkatan minat belajar siswa yang distimulasi dari pengorganisiran seluruh komponen pembelajaran secara maksimal. Penelitian ini akan menggambarkan proses peningkatan minat belajar siswa. Sejalan dengan tujuan ini pertanyaan dirumuskan: (1) Bagaimana tingkat minat belajar bahasa Arab pada siswa Madrasah Tsanawiyah, (2) Bagaimana tingkat kemampuan berbicara bahasa Arab yang dimiliki siswa Madrasah Tsanawiyah. Jawaban dari pertanyaan ini dapat berkontribusi dalam menyelesaikan problemaproblema oleh siswa pada proses belajar bahasa Arab di kelas.

Penelitian ini didasari pada dua argumentasi. Pertamaminat belajar seorang siswa yang tinggi bisa membantu siswa dalam meningkatkan kemampuan berbicara bahasa Arab. Tanpa adanya minat yang tinggi siswa tidak akan tertarik dalam mengikuti proses pembelajaran bahasa Arab. Siswa yang mempunyai minat belajar tinggi akan cenderung lebih banyak melakukan suatu kegiatan dan lebih cepat dalam memahami proses pembelajaran bahasa Arab.Keduatanpa adanya dukungan lingkungan belajar siswa maka peningkatan kemampuan berbicara dan minat belajar seorang siswa tidak akan berhasil. Tidak adanya dukungan dari lingkungan tersebutakan menimbulkan ketidak tertarikan siswa dalam proses belajar bahasa Arab. Sehingga tujuan peningkatan minat belajar dan kemampuan berbicara tidak akan tercapai jika siswa mendapatkan pengaruh lingkungan yang tidak baik. 


\section{Studi Literatur}

\section{a. Minat Belajar}

Dalam minat belajar tersusun dari dua kata yaitu minat dan belajar, maka dari itu kita harus mengetahui devinisi dari minat dan apa pengertian dari belajar. Minat merupakan karakteristik kemampuan yang dimiliki seseorang untuk memfokuskan perhatian seseorang dengan kemauan tinggi yang tergantung pada bakat dan lingkungan seseorang (Rusmiati, 2017). Minat juga bisa diartikan sebagai suatu keinginan diri pada sesuatu seperti perasaan senang, kesenangan, memperhatikan dan adanya motif serta tujuan dalam mencapai suatu tujuan yang diinginkan(Sirait, 2016).Minat menggambarkan adanya rasa ketertarikan dan keinginan yang tinggi pada seseorang untuk mendapatkan suatu keterampilan ataupun ilmu, adanya keterampilan ini akan menghasilkan dampak yang positif untuk seorang siswa dalam mengikuti proses belajar didalam kelas serta akan memicu kesadaran siswa agar dapat mendorong diri serta kemampuan siswa tersebut dalam memperoleh hasil yang maksimal dengan tekun belajar sesuai yang diinginkan(Handayani et al., 2020).Sedangkan belajar dapat kita pahami sebagai peralihan perbuatan seseorang yang ditimbulkan dari bimbingan dan hasil suka duka kehidupan seseorang.

Jadidapat diambil kesimpulan dari berbagai pandangan diatas bahwa minat belajar merupakan suatu modal bagi siswa untuk melakukan suatu kegiatan belajar untuk mencapai sesuatu perubahan perilaku seseorang, yang dimaksud dengan perubahan perilaku ini adalah perubahan perilaku yang belum diketahui menjadi tahu. Minat belajar siswa merupakan suatu keinginan dan kemampuan siswa yang disertai dengan keaktifan yang disengaja dan perhatian siswa yang lebih fokus dan pada akhirnya akan menimbulkan rasa senang pada perubahan tingkah laku, baik itu berupa pengetahuan siswa yang bertambah, perubahan sikap serta keterampilan siswa dalam berbicara. Fungsi adanya minat pada seorang siswa sebagai berikut: (a) Sebagai pendorong semangat yang kuat dalam belajar, dibandingkan dengan siswa yang kurang tertarik dalam suatu aktivitas tertentu siswa yang tertarik atau berminat akan berusaha lebih giat dalam beraktivitas baik itu belajar ataupun bermain, (b)Bentuk intensitas apresiasi seorang siswa akan dipengaruhi oleh minat, semakin besar minat siswa dapat dilihat pada kegiatan di kelas atau bahkan di luar kelas ketika seorang siswa mulai berpikir tentang kegiatan yang akan mereka lakukan yang mendukung tercapainya apresiasi tersebut, (c) Menambah semangat pada setiap kegiatan yang dilakukan siswa. Siswa yang mempunyai minat tinggi terhadap sesuatu kegiatan maka pengalaman mereka akan jauh lebih menyenangkan dibandingkan dengan siswa yang merasa bosan karena tidak ada unsur keterpaksaan dalam melakukan kegiatan tersebut (Rahmayanti et al., 2016).

Mengembangkan minat pada siswa pada dasarnya membantu untuk melihat bagaimana keterkaitan antara dirinya sebagai individu dengan yang diharapkan untuk dipelajari siswa tersebut. Hal ini untuk menunjukkan kepada siswa bagaimana kemampuan atau pengetahuan tertentu memotivasi dirinya, memenuhi tujuan yang 
ingin dicapai, dan memuaskan kebutuhannya dengan adanya minat tersebut. Jika siswa sadar bahwa belajar itu merupakan salah satu alat untuk mencapai suatu tujuan yang dianggap siswa penting, dan jika siswa bisa melihat bahwa hasil dari sebuah pengalaman belajarnya bisa membawa kemajuan yang bersifat positif untuknya, kemungkinan besar siswa tersebut akan berminat. Minat merupakan suatu perangkat mental pada diri seseorang yang berupa campuran dari harapan seseorang, pendirian, perasaan, perasangka, rasa takut dan kesecenderungan lain yang mengarahkan siswa tersebut pada suatu pilihan tertentu.

Minat pada seorang siswa juga bisa dibedakan menjadi 2 macam, diantaranya yaitu minat aktual yang biasa disebut juga dengan perhatian ketika dalam proses pembelajaran dan minat disposisional yang merupakan minat siswa yang mengarah pada pembawaan. Minat bukanlah sesuatu yang dibawa manusia sejak lahir dan bukan pula keseluruhan yang tidak bisa dirubah, maka dari itu seseorang yang mempunyai minat rendah dapat dirubah minatnya menjadi tinggi. Minat merupakan sebuah hasil dari proses belajar atau pengalaman seseorang. Didalam minat terdapat dua aspek penting yang perlu kita ketahui, diantaranya: (1) Aspek kognitif, aspek ini didasari atas pengalaman yang didapat siswa dan apa yang dapat dipelajari dari lingkungan kehidupan siswa, (2) Aspek afektif, aspek ini merupakan konsep pembangun aspek kognitif yang diwujudkan dalam bentuk sikap terhadap segala kegiatan yang dapat meningkatkan sebuah minat siswa (Asal et al., n.d.).

Tidak adanya minat pada diri seorang siswa terhadap suatu pelajaran akan timbul kesulitan pada saat proses pembelajaran berlangsung. Belajar yang tidak didasari dengan minat mungkin tidak sesuai dengan kecakapan, tidak sesuai dengan bakat yang siswa miliki karena itulah pelajaran yang diberikan tidak pernah terjadi proses dalam otak dan akan menimbulkan kesulitan dalam belajar. Ada atau tidaknya minat pada seorang siswa dapat kita lihat dari bagaimana cara seorang anak mengikuti proses pembelajaran di kelas, lengkap tidaknya catatan yang diberikan oleh guru, memperhatikan ada tidaknya garis miring dalam pelajaran itu terutama bahasa Arab. Dari tanda-tanda ini bisa dilihat apa penyebab dari kesulitan belajar yang dialami seorang siswa yaitu disebabkan karena tidak adanya minat pada diri siswa dalam mengikuti proses belajaran dikelas.

Terdapat empat indikator yang bisa digunakan untuk mengukur minat belajar pada siswa diantaranya yaitu (1) Ketertarikan siswa dalam belajar hal ini dapat diartikan jika seseorang yang mempunyai minat belajar maka rasa ketertarikan terhadap suatu pelajaran akan tinggi, ia akan mengikuti proses pembelajaran dengan sangat antusias dan senang hati tanpa membebani diri sendiri, (2) Perhatian siswa dalam belajar, perhatian dalam hal ini dapat diartikan sebagai suatu konsentrasi seseorang dalam pengamatan. Jika seseorang mempunyai perhatian pada saat belajar, maka konsentrasinya akan terfokus dengan apa yang sedang dipelajarinya, (3) Motivasi yang dimiliki siswa, adanya motivasi ini sangat penting untuk seseorang dalam proses belajar agar seseorang terdorong untuk belajar secara terarah guna pencapaian tujuan 
dari belajar, dan (4) Ilmu pengetahuan yang dapat diartikan seseorang yang mempunyai minat belajar tinggi pastinya akan mempunyai pengetahuan yang luas serta mengetahui manfaat dari belajar dalam kehidupan sehari-hari(Andriani \& Rasto, 2019).Cara membangkitkan minat belajar pada siswa yang efektif adalah bisa menggunakan minat-minat yang sudah dimiliki siswa dan mengembangkan minat tersebut serta menciptakan suatu minat baru pada diri siswa. Membangkitkan minat belajar siswa ini juga bisa dengan cara menggabungkan materi pelajaran yang ada dengan hal-hal yang sudah banyak diketahui siswa-siswa(Budiwibowo, 2016).

Dalam belajar terdapat faktor-faktor yang dapat mendorong minat belajar pada siswa diantaranya yaitu: (1) Motivasi dan cita-cita, motifasi dan cita-cita ini bisa sebagai pendorong yang kuat adanya minat belajar agar tercapainya suatu tujuan yang diinginkan,(2) Keluarga, keluarga bisa menjadi faktor pendorong adanya minat belajar karena keluarga merupakan tempat atau pusat pendidikan yang paling utama, (3) Peranan guru, guru yang berperan sebagai fasilitator pembelajaran dan yang mengetahui kharakteristik unik setiap masing-masing siswa bisa menjadi faktor pendorong agar siswa tidak malas dan minat dalam belajar, (4) Sarana dan Prasarana, yang bisa mendorong minat belajar adalah adanya rasa kenyamanan sehingga fasilitas yang ada disekolah sangatlah penting untuk meningkatkan minat belajar siswa, (5) Teman Pergaulan, minat seorang teman yang tinggi bisa mempengaruhi minat belajar pada diri seorang siswa baik teman dilingkungan sekolah ataupun dilingkungan luar sekolah, (6) Mass Media, mass media yang bisa mempengaruhi minat belajar diantaranya yaitu radio, televisi, video visual dan media cetak lainnya seperti koran, majalah, surat kabar ataupun buku-buku bacaan(Simbolon, 2014).

\section{b. Kemampuan Berbicara}

Kemampuan disebut juga sebagai keterampilan merupakan kemampuan siswa untuk melakukan segala aktivitas dalam usahanya untuk menyelesaikan sebuah tugas (Ningsih, 2014). Sedangkan berbicara merupakan kemampuan seseorang untuk mengatakan suara dengan artikulasi atau kata-kata untuk mengekspresikan diri atau menyampaikan suatu pikiran, gagasan, dan perasaan seseorang kepada lawan bicara (Hidayati, 2018).Selain sebagai modal utama bagi siswa untuk mempelajari susatu bahasa, keterampilan berbicara juga mempunyai peran penting dalam kehidupan siswa terutama pada kehidupan sosial karena yang sangat diperlukan siswa dan masyarakat untuk berkomunikasi dalam kehidupan sehari-hari yaitu berbicara yang merupakan alat komunikasi(Asmah, 2018).Kemampuan bicara seorang siswa bisa dilihat dan sesuai dengan kenyataan apabila teknik dalam penilaian yang digunakan tepat, karena penilaian ini merupakan bagian penting dalam proses pembelajaran terutama pembelajaran berbicara ini untuk mengetahui dan memahami siswa dalam perkembangan kemampuan atau keterampilan berbicaranya (Sintadewi et al., 2017).

Tes berbicara yang dapat dilakukan untuk memperkirakan seberapa kemampuan dalam berkomunikasi siswa menggunakan bahasa lisan diantaranya 
wawancara, bercerita dan berdiskusi dengan memperhatikan komponen-komponen tekanannya, tata bahasa yang digunakannya, kosakata yang dikuasainya, kelancaran serta pemahaman ketika berkomunikasi (Nandaliana Indratayana et al., 2016). Berbagai definisi mengenai berbicara bahwa berbicara merupakan salah satu kemampuan berkomunikasi seseorang dengan lawan bicaranya melalui media bahasa, hakikat berbicara pada dasarnya meliputi: (1) Berbicara merupakan wujud individu berkomunikasi, (2) Berbicara menjadi salah satu media untuk memperluas ilmu pengetahuan, (3) Berbicara adalah ekspresi kreatif dan tingkah laku, (4) Komunikasi yang seiring seperti berbicara dengan menyimak, (5) Pada konteks komunikasi dengan lawan bicara, berbicara adalah komunikasi timbal balik atau bersifat saling berbalasan, (6) Perbicara merupakan wujud individu berkomunikasi(Setyonegoro, 2013).

Ada dua bentuk kemampuan berbicara pada seseorang diantaranya yaitu: (a) Monologika yang dimana hanya ada satu orang yang berbicara. Bentuk dari monologika ini yang sangat penting yaitu proses siswa dalam menyampaikan sebuah pendapat atau ide kepada orang lain didepan umum, dengan demikian siswa akan belajar memberanikan diri berbicara menggunakan bahasa Arab, (b)Dialogika yang dimana ini merupakan kemampuan berbicara seseorang dalam berdialog dengan dua orang atau lebih. Melatih dialogika ini bisa dengan diskusi, berunding, melakukan tanya jawab, debat ataupun dengan percakapan biasa. Keterampilan berbicara ini perlu dikuasai dengan baik, karena indikator keberhasilan seseorang dalam belajar bahasa adalah keterampilan berbicara yang baik dan santun. Dengan penguasaan bahasa yang baik, seseorang bisa mengolah perkataan yang akan diungkapkan kepada orang lain sesuai ide-ide mereka dengan baik. Didalam keterampilan berbicara juga perlu menguasai empat kompetensi diantara yaitu sosiolinguistik, diskursus, gramatika dan strategi (Nuryanto et al., 2018).

Keterampilan bericara siswa akan mudah dikembangkan apabila seorang siswa dapat berkomunikasi secara alami kepada lawan bicaranya. Tujuan dari keterampilan berbicara ini yaitu untuk melatih siswa agar mampu serta terampil dalam berbicara, keterampilan ini bisa dilatih dengan memberikan kesempatan kepada siswa untuk penyampaikan pendapatnya secara langsung dengan memperhatikan kelancaran berbicaranya. Selain itu kemampuan berbicara ini juga merupakan sarana berkomunikasi dengan orang lain dan untuk memahami apa yang diingin pembicara. Pembelajaran ini bisa dimulaisetelah siswa sudah mengetahui bagaimana bunyi-bunyi huruf Arab yang benar dan bisa membedakan bunyi antara huruf satu dengan bunyi huruf yang lainnya. Tujuan berbicara ini selain untuk alat komunikasi juga sebagai alat menghibur, menginformasi, menstimulasi, meyakinkan dan menggerakkan (Permana, 2015).

Kesalahan-kesalahan dalam berbicara dapat diklarifikasikan menjadi 5 jenis kesalahan diantaranya (1) Kesalahan intonasi saat berbicara, (2) Kesalahan ketika dalam pelafalan, (3) Kesalahan dalam penggunaan kalimat yang tepat, (4) Kelancaran berbicara, (5) Kenyaringan. Sedangkan kesalahan dalam segi kalimat dibagi dalam tiga 
jenis, diantaranya kesalahan dalam pemilihan kata yang tepat, kesalahan dalam penggunaan afiks dan ketidakefektifan kalimat yang digunakan ketika berbicara. Ada beberapa faktor yang bisa menjadi sebab seorang siswa melakukan kesalahan ketika berbicara diantaranya grogi atau gugup yang disebabkan oleh faktor psikologi siswa, kurang menguasai topik, kurangnya penguasaan kosakata, dan kurangnya pemahaman tata bahasa serta tata kalimat (Budiawan \& Rukayati, 2018).

Didalam keterampilan berbicara juga diperlukan proses evaluasi keterampilan berbicara, diatara hal-hal yang bisa dilakukan yaitu: (1) Menetapkan permasalahan (2) Menetapkan tujuan, penetapan tujuan ini bisa berupa apakah evaluasi keterampilan berbicara ini bertujuan untuk menguji kebenaran pelafalan huruf, susunan kata ataupun ungkapan-ungkapan lancar mereka bicarakan, (3) Persiapan ujian, persiapan ini berupa persiapan alat apa saja yang digunakan ketika evaluasi baik berupa materi atau soal-soal yang akan diberikan kepada anak sesuai standar penilaian, (4) Pelaksanaan dan(5) Perbaikan, proses perbaikan ini akan dilakukan apabila hasil evaluasi tidak sesuai dengan target yang ingin dicapai (Berbicara et al., n.d.).

\section{Metode}

Penelitian ini menganalisis tentang minat belajar dan kemampuan berbicara bahasa Arab siswa. Tempat penelitian ini bertempat di Madrasah Tsanawiyah Negeri 2 Lampung Tengah. Pemilihan lokasi didasari pada madrasah yang memiliki fasilitas yang memadai untuk meningkatkan minat belajar dan kemampuan berbicara bahasa Arab siswa.

Penelitian ini termasuk dalam penelitian surveyuntuk menganalisis minat belajar dan kemampuan berbicara bahasa Arab siswa. Teknik survey merupakan teknik pengumpulan data atau informasi yang didapat dari responden menggunakan angket atau kuesioner sebagai alat pengumpulan data dengan menggunakan sampel sebagai sumber data primer. Secara umum ada tujuh langkah dalam pengambilan data menggunakan teknik survey diantaranya sebagai berikut: (1) Menentukan informasi apa yang ingin diperoleh melalui survey, (2) Sampel penelitian ditentukan dari beruapa jumlah responden, (3) Menyusun pertanyaan kuesioner, (4) Menentukan metode survey, apakah melalui telepon atau secara langsung, (5) Mengumpulkan data di lapangan, (6)Memproses data yang sudah diperoleh, (7) Menggunakan hasil survey untuk menyusun laporan.

Teknik pengumpulan data menggunakan angket dan test. Instrumen angket digunakan untuk mengetahui tingkat minat siswa dalam belajar bahasa Arab. Instrumen test digunakan untuk mengetahui tingkat kemampuan berbicara bahasa Arab. Test dilakukan bersama guru setelah akhir pembelajaran. Responden penelitian ini adalah siswa kelas VIII Madrasah Tsanawiyah Negeri 2 Lampung Tengah yang berjumlah 52 siswa.Teknik analisis data yang digunakan adalah kuantitatif deskriptif yang merupakan suatu teknik analisis yang datanya diperoleh dari sampel populasi penelitian yang harus dianalisis sesuai dengan metode statistik yang digunakan. 


\section{Hasil Penelitian}

\section{a. Tingkat Minat Belajar Bahasa Arab Siswa Madrasah Tsanawiyah}

Salah satu hal yang juga penting dan perlu diperhatikan dalam proses pembelajaran bahasa Arab adalah minat belajar. Minat belajar siswa yang tinggi akan menimbulkankesadaran dan rasa ingin mengetahui yang tinggi saat belajar serta cepat mengingat dan memahami pelajaran bahasa Arab yang diberikan. Sebaliknya apabila minat belajar siswa rendah maka akan menimbulkan kurang tertariknya siswa dalam mengikuti pembelajaran bahasa Arab, bahkan cenderung menimbulkan sikap penolakan kepada guru.

Guru sangat berperan penting dalam meningkatkan minat belajar siswa. Selain sebagai motivator, seorang guru juga berperan sebagai edukator untuk mencontohkan sikap, perilaku dan kepribadian peserta didik menjadi lebih baik. Guru juga menjadi seorang supervisor, hal ini terkait dengan pemberian pengawasan serta bimbingan kepada siswa, memahami dalam proses pembelajaran masalah apa saja yang dihadapi oleh siswa, dan menemukan jalan keluar jika ada masalah dalam proses pembelajaran. Selain itu guru juga harus menjadi innovator, dalam hal ini guru harus mempunyai kemauan tinggi dalam belajar untuk menambah pengetahuan dan keterampilannya menjadi seorang guru yang profesional. Tanpa semangat yang tinggi maka guru tidak akan bisa menghasilkan inovasi-inovasi yang tepat untuk meningkatkan mutu pembelajaran siswa disekolahan.

Hasil analisis data angket yang disebar pada 52 siswa menunjukkan minat belajar bahasa Arab siswa adalah berada pada rata-rata 32.3 yang berada pada rentang 21-40 yang bermakna rendah (tabel.1)

Tabel.1Tingkat Minat Belajar Bahasa Arab

\begin{tabular}{cccccccc}
\hline \multicolumn{8}{c}{ Descriptive Statistics } \\
\hline & $\mathrm{N}$ & Range & Minimum & Maximum & Mean & Std. Deviation & Variance \\
\hline $\begin{array}{c}\text { Minat Belajar } \\
\text { Bahasa Arab }\end{array}$ & 52 & 19.00 & 21.00 & 40.00 & 32.3269 & 5.30158 & 28.107 \\
\hline $\begin{array}{c}\text { Valid N } \\
\text { (listwise) }\end{array}$ & 52 & & & & & & \\
\hline
\end{tabular}

Pengukuran tingkat minat belajar bahasa Arab menggunakan skala likert dengan lima kelas interval yaitu rendah sekali, rendah, sedang, tinggi dan sangat tinggi dengan interval nilai 1-100 sebagaimana dilihat pada (tabel.2)

Tabel.2 Interval Nilai

\begin{tabular}{ccc}
\hline Interval & Predikat & Keterangan \\
\hline $81-100$ & $\mathrm{~A}$ & Sangat Tinggi \\
\hline $61-80$ & $\mathrm{~B}$ & Tinggi \\
\hline
\end{tabular}




\begin{tabular}{clc}
\hline $41-60$ & C & Sedang \\
\hline $21-40$ & D & Rendah \\
\hline $0-20$ & E & Rendah Sekali \\
\hline
\end{tabular}

\section{b. Tingkat Kemampuan Berbicara Bahasa Arab Siswa Di Madrasah Tsanawiyah}

Kemampuan atau keterampilan dalam belajar menjadi salah satu kemampuan yang perlu dikuasai oleh siswa dalam proses belajar. Siswa yang memiliki kemampuan berbahasa akan mudah saat berkomunikasi dan berinteraksi dengan seseorang dan memudahkan seseorang yang ingin menyampaikan informasi baik secara lisan langsung atau tulisan. Kemampuan berbicara ini sangat penting untuk dikuasai karena dalam sehari-hari siswa akan bertemu banyak orang dan berinteraksi satu sama lain terutama pada saat pembelajaran bahasa Arab siswa harus aktif dan terampil dalam berbahasa Arab.

Hasil analisis data test pada 52 siswa menunjukkan minat belajar bahasa Arab siswa adalah berada pada rata-rata 61.03 yang berada pada rentang $<75$ yang bermakna kurang (tabel.1)

Tabel.1 Tingkat Kemampuan Berbicara Bahasa Arab

\begin{tabular}{|c|c|c|c|c|c|c|c|}
\hline \multicolumn{8}{|c|}{ Descriptive Statistics } \\
\hline & $\mathrm{N}$ & Range & Minimum & Maximum & Mean & Std. Deviation & Variance \\
\hline $\begin{array}{c}\text { Berbicara } \\
\text { Bahasa Arab }\end{array}$ & 52 & 33.00 & 40.00 & 73.00 & 61.0385 & 8.89803 & 79.175 \\
\hline $\begin{array}{c}\text { Valid N } \\
\text { (listwise) }\end{array}$ & 52 & & & & & & \\
\hline
\end{tabular}

Pengukuran tingkat kemampuan berbicara bahasa Arab menggunakan skala likert dengan 4 kelas interval yaitu kurang, cukup, baik dan sangat baik dengan interval nilai 1-100 sebagaimana dilihat pada (tabel.2)

Tabel.2 Interval Nilai

\begin{tabular}{ccc}
\hline Interval & Predikat & Keterangan \\
\hline $93-100$ & $\mathrm{~A}$ & Sangat Baik \\
\hline $84-92$ & $\mathrm{~B}$ & Baik \\
\hline $75-83$ & $\mathrm{C}$ & Cukup \\
\hline$<75$ & $\mathrm{D}$ & Kurang \\
\hline
\end{tabular}

\section{Pembahasan}

Hasil analisis tentang minat belajar bahasa Arab pada siswa kelas VIII di Madrasah Tsanawiyah Negeri 2 Lampung Tengah berada pada level rendah dan tingkat 
kemampuan berbicara pada level kurang. Minat belajar yang rendah berdampak pada proses belajar siswa tidak kondusifsehingga kemampuan berbicara bahasa Arab juga rendah. Hal ini disebabkan karenaminat yang tinggi melahirkan perilaku diantaranya senang dan sama sekali tidak ada perasaan terpaksa saat mengikuti proses belajar didalamkelas, seorang siswa akan tertarik mengikuti proses pembelajaran dari guru dan siswa sangat perhatian dalam proses pembelajaran dengan sangat konsentrasi dengan mengesampingkan hal yang lain. Minat belajar yang rendah melahirkan prilaku siswa yang tidak akan memperhatikan ketika proses pembelajaran berlangsung, tidak akan senang dan merasa terpaksa mengikuti proses pembelajaran dikelas dan akan menimbulkan sikap penolakan terhadap apapun yang diberikan guru saat proses pembelajaran berlangsung. Peningkatan minat belajar siswa bisa membantu siswa dalam meningkatkan kemampuan berbicara bahasa Arab. Tanpa adanya minat yang tinggi maka siswa tidak akan tertarik dalam mengikuti proses pembelajaran bahasa Arab.

Minat belajar merupakan faktor yang sangat penting untuk meningkatkan hasil belajar, karena siswa akan belajar dengan sungguh-sungguh dan merasa senang ketika menyukai pelajaran tersebut dan akan mendapatkan hasil belajar yang maksimal. Seorang siswa yang mempunyai minat tinggi dalam mengikuti proses pembelajaran tidak akan menjadikan hambatan sebagai kendala dalam belajar di waktu kapanpun baik di waktu siang atau di waktu pagi, mereka akan terus bersemangat mengikuti proses pembelajaran di kelas. Siswa akan bisa mengendalikan dirinya sendiri ketika minat belajar pada dirinya besar, sehingga ia bisa meningkatkan hasil belajarnya dengan baik. Sedangkan siswa yang tidak bisa memotivasi dirinya sendiri akan cenderung memiliki minat yang rendah sehingga tidak bisa mendapatkan hasil belajar yang diharapkan.

Peningkatan minat belajar dan kemampuan berbicara tidak akan berhasil tanpa adanya dukungan dari lingkungan belajar siswa. Tidak adanya dukungan dari lingkungan tersebut akan menimbulkan ketidaktertarikan siswa dalam proses belajar bahasa Arab. Sehingga peningkatan minat belajar dan kemampuan berbicara tidak akan tercapai. Lingkungan yang dimaksud salah satunya adalah guru yang tepat dalam penggunaan media serta metode pembelajaran di kelas.Berbagai suasana di kelas dapat tercipta dengan adanya penggunaan metode dan media pembelajaran yang tepat serta. Pembelajaran di kelas akan lebih menyenangkan jika guru dapat menggunakan media pembelajaran yang sesuai. Interaksi guru dengan siswa akan berjalan lancar sehingga pembelajaran berjalan efektif serta efisien jika seorang guru menggunakan media belajar.Selain media, metode juga sangat berperan penting untuk membantu guru dalam pembelajaran diantaranya metode berperan sebagai acuan guru dalam perencanaan pembelajaran, sebagai alat untuk mencapai tujuan pembelajaran, sebagai alat agar pembelajaran berjalan dengan menyenangkan, apabila dalam pemilihan metode tepat materi akan diterima dengan baik oleh siswa dan sebagai alat untuk 
menilai ketuntasan hasil belajar dengan pemilihan metode pembelajaran yang tepat serta dapat meningkatkan minat siswa.

Kemampuan berbicara ini tidak bisa didapatkan secara langsung oleh semua orang, sebagian orang memerlukan latihan dan pengalaman berbicara yang benar. Bicara merupakan sistem komunikasi untuk seseorang mengutarakan pendapat maupun perasaan dan mengerti maksud pembicaraan orang lain melalui mendengar. Kemampuan berbicara siswa bisa ditingkatkan melalui latihan, siswa bisa diajak berlatih terampil dalam berbicara dalam kelas dengan teman-temannya secara langsung dalam pengawasan guru, sehingga jika dalam proses pembelajaran ini terjadi kesalahan, maka guru bisa memperbaikinya secara langsung. Dalam latihan, guru harus berusaha memberikan kesempatan kepada siswa untuk mengembangkan kemampuan berbicaranya. Melalui pembelajaran kemampuan berbicara secara terpadu, seorang guru bisa memberikan pengalaman kepada siswa yang menggunakan proses yang saling berkaitan dengan kondisi yang ada disekitar siswa.

Langkah-langkah pembelajaran kemampuan berbicara untuk siswa tingkat menengah guru bisa melakukan beberapa hal berikut, diantaranya belajar berbicara dengan menggunakan metoderole playing, berdiskusi tentang tema menarik yang sudah ditentukan, bercerita tentang peristiwa yang dialami siswa dalam kehidupan sehari-harinya dan bercerita kembali tentang informasi yang didapat. Tahapan dalam pembelajaran kemampuan berbicara ini diantanya adalah (1) Berawal dari ungkapan yangsederhana atau pendek terlebih dahulu, hendaknya dilakukan dalam kondisi yang senyata mungkin agar siswa mudah mengungkapkannya, setelah itu dilanjutkan dengan ungkapan yang lebih panjang, (2) Siswa harus terus diberi motivasi untuk berkomunikasi dengan tema kegiatan sehari-hari siswa yang pendek, kemudian secara perlahan ditingkatkan lebih panjang, (3) agar terbiasa dengan lahjah penutur aslinya, siswa bisa diberi tugas untuk sering mendengarkan dialok berbahasa Arab melalui video ataupun rekaman.

Dalam proses pembelajaran kemampuan berbicara ini membutuhkan keahlian dalam kemampuan berbicaraguru yang sehari-harinya banyak berhadapan dengan siswa. Guru harus lebih sering berinteraksi dengan siswa menggunakan bahasa Arab agar siswa terbiasa. Guru yang berkualitas hendaknya mampu menciptakan proses pembelajaran yang baik dan menarik. Minat belajar dan kemampuan berbicara siswa akan meningkat apabila dalam proses pembelajaran yang diberikan tepat dan menarik.Dalam meningkatkan minat belajar, guru dapat menerapkan beberapa hal berikut diantaranya: (a) pada saat pembelajaran dikelas guru dapat membentuk kelompok dengan tujuan mengurangi rasa grogi siswa, (b) menggunakan bahasa yang mudah berdasarkan aktivitas sehari-hari dengan menyesuaikan kemampuan berbicara siswa, (c) memilih topik yang dapat menarik perhatian siswa agar siswa berminat mengikuti proses pembelajaran, (d) memberikan arahan kepada siswa dan (e) selalu mengawasi, selalu ada dan mengingatkan siswa agar selalu menggunakan bahasa Arab ketika proses belajar berlangsung. 
Jika usaha tersebut tidak menimbulkan hasil, guru bisa menggunakan cara insentif dengan mengajak siswa melakukan sesuatu hal yang belum dilakukan dengan baik. Dengan harapan dapat meningkatkan motivasi dan minat belajar bahasa Arab siswa. Menghukum siswa karena tidak ada peningkatan terbukti tidak efektif, bahkan hukuman yang terlalu sering diberikan bisa membuat siswa tidak berminat dalam belajar dan menghambat belajar. Guru yang akan menggunakan cara insentif harus bisa bersikap bijaksana dan harus bisa disesuaikan dengan diri masing-masing siswa.Dari pembahasan ini bisa dilihat bahwa lingkungan sangat berperan dalam meningkatkan minat siswa. Bukan hanya teman tetapi guru yang tepat dalam pemilihan metode dan media pembelajaran juga sangat berpengaruh dalam meningkatkan minat belajar dalam kemampuan berbicara siswa. Pemilihan metode dan media yang tepat akan membuat siswa senang dan dapat mengoptimalkan proses pembelajaran sehingga akan menghasilkan output yang memuaskan termasuk meningkatnya minat belajar siswa dan kemampuan berbicara.

\section{Kesimpulan}

Hasil penelitian menunjukkan bahwa tingkat minat belajar berada pada level rendah dan kemampuan berbicara pada level kurang. Minat belajar yang rendah ditunjukan pada prilakusiswa yang tidak tertarik dan tidak memperhatikan dalam mengikuti pelajaran. Siswa terpengaruh dengan lingkungan teman yang banyak kurang berminat dalam mengikuti proses pembelajaran bahasa Arab. Siswa lebih sering diam ketika proses pembelajaran berlangsung dengan berbagai alasan, seperti takut salah ketika berbicara atausiswa tidak ada keberanian untuk mengungkapkan walaupun siswa sebetulnya memiliki kemampuan dalam berbicara bahasa Arab.Siswa tidak senang dan merasa terpaksa mengikuti proses pembelajaran di kelas yang akan menimbulkan sikap penolakan terhadap apapun yang diberikan guru saat proses pembelajaran berlangsung.Lingkungan sangat berperan dalam peningkatan minat belajar yang akan mempengaruhi kemampuan berbicara bahasa Arab siswa. Selain teman, guru yang tepat dalam memilih media dan metode dalam proses pembelajaran juga sangat berpengaruh dalam peningkatan minat siswa. Dalam hal ini peningkatan minat belajar pada seorang siswa ditentukan oleh tindakan apa yang dilakukan seorang guru dalam proses mengajar dikelas. Minat atau ketertarikan siswa yang tinggi dapat melahirkan perilaku diantaranya senang dan sama sekali tidak ada perasaan terpaksa saat mengikuti proses belajar didalam kelas, seorang siswa akan tertarik mengikuti kegiatan belajar dari guru dan seorang siswa sangat perhatian dalam proses belajar dikelas dengan sangat konsentrasi dengan mengesampingkan hal yang lain.Kemampuan berbicara yang rendah disebabkan oleh guru yang mengajar monoton dan tidak memberi contoh dalam berbicara bahasa Arab. Dalam hal ini kemampuan berbicara siswa bisa ditingkatkan melalui latihan, siswa bisa diajak berlatih terampil dalam berbicara dalam kelas dengan teman-temannya secara langsung dan tetap dalam pengawasan seorang guru, sehingga apabila dalam proses pembelajaran ini terjadi 
kesalahan, maka guru bisa memperbaikinya secara langsung. Dalam latihan, kesempatan yang diberikan kepada siswa juga sangat penting untuk meningkatkan keterampilan berbicara siswa. Pengalaman pada seorang siswa yang diberikan oleh guru pada proses pembelajaran kemampuan berbicara secara sistematis serta menggunakan cara yang saling berhubungan dengan kondisi yang ada disekitar siswa karena dalam proses pembelajaran kemampuan berbicara ini membutuhkan keahlian dalam kemampuan berbicara guru yang sehari-harinya banyak berhadapan dengan siswa. Guru harus lebih sering berinteraksi dengan siswa menggunakan bahasa Arab agar siswa terbiasa. Guru yang berkualitas hendaknya mampu menciptakan suatu proses pembelajaran yang baik dan menarik dengan pemilihan media dan metode yang tepat. 


\section{Daftar Pustaka}

Andriani, R., \& Rasto, R. (2019). Motivasi belajar sebagai determinan hasil belajar siswa. $\begin{array}{lllll}\text { Jurnal Pendidikan Manajemen } & \text { Perkantoran, }\end{array}$ https://doi.org/10.17509/jpm.v4i1.14958

Asal, M., Dan, P., Barat, P., Kota, D. I., \& Kambuaya, C. (n.d.). No Title.

Asmah, A. (2018). Upaya Meningkatkan Keterampilan Berbicara Untuk Mengemukakan Pendapat Melalui Metode Diskusi Pada Siswa Kelas Vi. Paedagoria / FKIP UMMat, 9(1), 45. https://doi.org/10.31764/paedagoria.v9i1.275

Berbicara, K., Mustofa, B., \& Hamid, M. A. (n.d.). Evaluasi Keterampilan Berbicara Dalam Pembelajaran Bahasa Arab Oleh: Dony Ahmad Ramadhani* Abstrak. 9(17), 75-96.

Budiawan, R. Y. S., \& Rukayati, R. (2018). Kesalahan Bahasa Dalam Praktik Berbicara Pemelajaran Bahasa Indonesia Bagi Penutur Asing (Bipa) Di Universitas Pgri Semarang Tahun 2018. KREDO: Jurnal Ilmiah Bahasa Dan Sastra, 2(1). https://doi.org/10.24176/kredo.v2i1.2428

Budiwibowo, S. (2016). Hubungan Minat Belajar Siswa Dengan Hasil Belajar Ips Di Smp Negeri 14 Kota Madiun. Gulawentah:Jurnal Studi Sosial, 1(1), 60. https://doi.org/10.25273/gulawentah.v1i1.66

Handayani, D., Nurhayati, N., \& Herawati, H. (2020). Hubungan Antara Minat Belajar Siswa Dan Motivasi Belajar Terhadap Hasil Belajar Bahasa Inggris Siswa Kelas V Sd Negeri Cibuluh 6 Kota Bogor. Jurnal Teknologi Pendidikan, 9(1). https://doi.org/10.32832/tek.pend.v9i1.2710

Hernawati, T. (2007). Pengembangan Kemampuan Berbahasa Dan Berbicara Anak Tunarungu. Juni.

Hidayati, A. (2018). Peningkatan Keterampilan Berbicara Melalui Pendekatan Komunikatif Kelas V Sd Padurenan Ii Di Bekasi Tahun Pelajaran 2016/2017. Jurnal Ilmiah Pendidikan Dasar, 5(2), 83. https://doi.org/10.30659/pendas.5.2.83-95

Mainizar. (2011). Korelasi motivasi belajar bahasa arab dengan minat berkomunikasi dalam bahasa arab pada mahasiswa jurusan pendidikan bahasa arab fakultas tarbiyah dan keguruan universitas islam negeri sultan syarif kasim riau. Jurnal Sosial Budaya, 8(01), 97-113.

Nandaliana Indratayana, N., Simpen, I., \& Sedeng, I. (2016). Penilaian Keterampilan Berbicara Dalam Pembelajaran Bahasa Indonesia Sebagai Bahasa Asing. Linguistika, 23(45), 184-195.

Ningsih, S. (2014). Peningkatan Keterampilan Berbicara melalui Metode Bercerita Siswa Kelas III SD Negeri 1 Beringin Jaya Kecamatan Bumi Raya Kabupaten Morowali. Jurnal Kreatif Tadulako Online, 2(4), 243-256. http://jurnal.untad.ac.id/jurnal/index.php/JKTO/article/download/3990/2944

Nurhasanah, S., \& Sobandi, A. (2016). Minat Belajar Sebagai Determinan Hasil Belajar Siswa. Jurnal Pendidikan Manajemen Perkantoran. https://doi.org/10.17509/jpm.v1i1.3264

Nuryanto, S., Abidin, A. Z., Setijowati, U., \& Sb, N. S. (2018). Peningkatkan Keterampilan 
Berbicara Mahasiswa Pgsd Dalam Perkuliahan Bahasa Indonesia Berbasis Konservasi Nilai-Nilai Karakter Melalui Penerapan Metode Task Based Activity Dengan Media Audio Visual. Jurnal Penelitian PendidikanA \& A (Semarang), 35(1), 83-94. https://doi.org/10.15294/jpp.v35i1.15095

Permana, E. P. (2015). Pengembangan Media Pembejaran Boneka Kaus Kaki Untuk Meningkatkan Keterampilan Berbicara Siswa Kelas Ii Sekolah Dasar. Profesi Pendidikan Dasar, 2(2), 133-140. https://doi.org/10.23917/ppd.v2i2.1648

Qomariah, S. S., \& R Sudiarditha, I. K. (2017). Kualitas Media Pembelajaran, Minat Belajar, Dan Hasil Belajar Siswa: Studi Pada Mata Pelajaran Ekonomi Di Kelas X Iis Sma Negeri 12 Jakarta. Jurnal Pendidikan Ekonomi Dan Bisnis (JPEB), 4(1), 46. https://doi.org/10.21009/jpeb.004.1.3

Rahmayanti, V., Studi, P., \& Informatika, T. (2016). Jurnal SAP Vol . 1 No . 2 Desember 2016 ISSN : 2527-967X Pengaruh Minat Belajar Siswa Dan Persepsi Atas Upaya Guru Dalam Memotivasi Belajar Siswa Terhadap Prestasi Jurnal SAP Vol . 1 No . 2 Desember 2016 ISSN : 2527-967X. 1(2), 206-216.

Ricardo, R., \& Meilani, R. I. (2017). Impak Minat dan Motivasi Belajar Terhadap Hasil Belajar Siswa. Jurnal Pendidikan Manajemen Perkantoran. https://doi.org/10.17509/jpm.v2i2.8108

Rusmiati. (2017). Pengaruh Minat Belajar Terhadap Prestasi Belajar Bidang Studi Ekonomi Siswa Ma Al Fattah Sumbermulyo. Jurnal Ilmiah Pendidikan Dan Ekonomi, 1(1), 2136.

Setyonegoro, A. (2013). Hakikat, Alasan, dan Tujuan Berbicara (Dasar Pembangun Kemampuan Berbicara Mahasiswa). Jurnal Pena, 3 (1)(1), 67-80.

Simbolon, N. (2014). Faktor-faktor yang mempengaruhi minat belajar peserta didik. Elementary School Journal Pgsd Fip Unimed, 1(2), 14-19. https://doi.org/10.24114/ESJPGSD.V1I2.1323

Sintadewi, N. G. A., Sriasih, S. A. P., \& Sudiana, I. N. (2017). Teknik Penilaian Keterampilan Berbicara Dalam Pembelajaran Bahasa Indonesia Di SMA Negeri 4 Denpasar. EJournal Pendidikan Bahasa Dan Sastra Indonesia, 7(2), 1-12.

Sirait, E. D. (2016). Pengaruh Minat Belajar Terhadap Prestasi Belajar Matematika. Formatif: Jurnal Ilmiah Pendidikan MIPA, 6(1), 35-43. https://doi.org/10.30998/formatif.v6i1.750

Tambunan, N. (2016). Pengaruh Strategi Pembelajaran dan Minat Belajar Terhadap Kemampuan Berpikir Kreatif Matematis Siswa. Formatif: Jurnal Ilmiah Pendidikan MIPA. https://doi.org/10.30998/formatif.v6i3.993

Tarigan, H. G. (2015). Berbicara: Sebagai Suatu Keterampilan Berbahasa. In Penerbit Angkasa. 